\title{
血中に投与したマルトースの代謝
}

\author{
郡 英 明*, 武 藤 泰 敏**, 細 谷 憲 政** \\ *(株)大塚製薬工場技術部 ** 東京大学医学部保健栄荃学教室
}

\section{Metabolism of Circulating Maltose in Guinea Pig}

\author{
Hideaki Kohri, * Yasutoshi Muto, ** Norimasa Hosoya** \\ * Technical Department, Otsuka Pharmaceutical Factory, Muya, Naruto, Tokushima \\ ** Nutritional Laboratory, School of Health Science, Faculty of \\ Medicine, The University of Tokyo, Bunkyo-ku, Tokyo
}

J. Jap. Soc. Food and Nutr., 25 (8), 641 646 (1972)

The metabolism of circulating maltose or glucose was studied in guinea pigs.

On the observation of excretion of radioactivity following intravenous administration of maltose$\mathrm{U}-{ }^{14} \mathrm{C}, 41 \%$ of the radioactivity was expired as respiratory ${ }^{14} \mathrm{CO}_{2}$ for 5 hours and $52 \%$ for 12 hours, and only $4 \%$ was excreted in the urine. The percentage of maltose oxidized to $\mathrm{CO}_{2}$ and excreted in the urine were similar to those of glucose.

On the observation of disappearance rate of maltose-U-14 $\mathrm{C}$ intravenously administered, biological half life of maltose-U-14C was 26 minutes and was similar to that of glucose-U-14 $\mathrm{C}$. No change of plasma glucose levels was observed and no maltase activity was detected in plasma, although glucose$\mathrm{U}-{ }^{14} \mathrm{C}$ originated from maltose- $\mathrm{U}-{ }^{14} \mathrm{C}$ appeared in plasma and its increasing tendency in concentration was observed until 30 minutes after administration.

On the observation of tissue distribution of radioactivity following intravenous administration of maltose-U_lit $\mathrm{C}$, distribution of radioactivity in the administration of maltose-U- ${ }^{14} \mathrm{C}$ were not similar to that in the administration of glucose-U-14 $\mathrm{C}$.

From these results, it is suggested that intravenously administered maltose is gradually converted to glucose and then metabolized to tissue constituents (ca. 50\%) or to respiratory $\mathrm{CO}_{2}(c a .50 \%)$.

Similar results were reported in rabbits and in human subjects.

Hence, parenteral administration of maltose would be of clinical value.

(Received July 20, 1972)

Weser $ら^{1)}$, Young $ら^{2}$ (は静脈内に投与したマルトー スが白ネズミとヒトに拉いてブドウ糖の場合と同様にエ ネルギー源として利用されることを報告している。この 場合、ヒトにおいては尿中への排泄は少なく，また血糖 值の上昇もみられないといら。

二糖類であるマルトースを血管内に投与した場合に は，マルトースはどのように細胞膜を通過して代謝され るのであろらか。二糖類の細胞膜透過に関する詳細な知 見は見当たらないが，小腸に怙いてはマルトースはブド ウ糖に分解されて吸収される。また，ブドウ糖を血管内 に投与するとインシュリンの分泌を促進するが，マルト 一スを投与した場合にはインシュリン分泌の促進は観察 されないというす。
そこで，マルトースを補液として利用できるかどらか を検討するため, マルトース-U-14C をモルモットに投 与した場合の血中よりの消失速度ならびに代謝様相につ いて観察し、ブドウ糖の場合と比較検討した。

\section{実 験 方 法}

\section{1. 試 料}

ブドウ糖は無水ブドウ糖（試薬特級, 和光純薬 K. K. 製)，マルトースは林原 K.K. 製（純度 $99 \%$ 以上4), たたし、ブドウ糖 0.04\%，マルトトリオース 0.7\%を 含む）のものを用いた。ブドウ糖は $5 \%$ ，マルトースは 10\%の等張水溶液を調製した。マルトースーU-14C は ICN, Tracer Lab. 社製 (Specific activity: $362 \mathrm{mCi}$ / 
m mole) またブドウ糖-U- ${ }^{14} \mathrm{C}$ は第一化学 K. K. 製 (Specific activity： $180 \mathrm{mCi} / \mathrm{m}$ mole) を使用した。

\section{2. 実 験 動 物}

体重 $300 \mathrm{~g}$ 前後の Hartley 系雄モルモット 6〜7 匹 を 1 群とし，慨ならびに水は自由に摂取させたが，糖質 を投与する場合には，6時間前より水のみを与えた。

\section{3. 投与実 験}

マルトース-U-14C，ないしはブドウ糖-U-14C を 0.1 $\mathrm{mg} / \mathrm{kg}(25 \mu \mathrm{Ci} / \mathrm{kg})$ ，あるいは $0.5 \mathrm{~g} / \mathrm{kg}(25 \mu \mathrm{Ci} / \mathrm{kg})$ をそれぞれモルモットの陰茥静脈より投与した。代謝ヶ 一ジ（容量 $1,230 \mathrm{~cm}^{3}$, 通気速度 $150 \mathrm{ml} / \mathrm{min}$ ) に入れ, 経時的に呼気および尿をそれぞれ採取した。またエーテ ル麻酔下で腹部大動脈より採血をおこない，さらに肝 蔵，腎臓，脳を取りたして，放射能の分布を観察した。

\section{4. 放 射能 測 定}

血将は Somogyi の方法5) で除タンパクした後, フェ ニールヒドラジン試薬を用いてマルトースあるいはブド ウ糖のオサゾンを生成し6)（回収率 95\%)，放射能測定 は日本無線医理学研究所 K. K. 製, TDC-2 型ガスフロ 一カウンターを用いて行なった（湘定効率 $48 \%$ )。

さらにマルトースを投与した場合には，マルトースお よびマルトース由来のブドウ糖を分離測定するため, 活 性炭を用いるカラムクロマトグラフィーを行なった7)。 3 倍希釈の除たん白濾液 $0.2 \mathrm{~m} l$ をカラムに重層し (10 $\times 30 \mathrm{~mm})$, 水 $45 \mathrm{ml}$ を用いてブドウ糖を溶出し, さら に $20 \%$ エタノール水溶液 $30 \mathrm{ml}$ を用いてマルトースを 溶出した。溶出液 $1.0 \mathrm{ml}$ を取り, ジオキサン系シンチ レーター（ナフタリン $110 \mathrm{~g}$, PPO $10 \mathrm{~g}$ および POPOP $0.25 \mathrm{~g}$ をジオキサンに溶かして $1 l$ にしたるの） $5.0 \mathrm{ml}$ を加え, Packard 社製, 3380 型液体シンチレーション スペクトロメーターを用いて放射能を測定した。

血中に投与された放射性ブドウ糖ならびにマルトース の生物学的半減期 (biological half life : BHL) は次式 を用いて求めた。

$$
\begin{aligned}
k t=l_{n} \frac{n_{0}}{n_{t}} & =2.303 \log \frac{n_{0}}{n_{t}} \\
t_{1 / 2}=\frac{l_{n} 2}{k} & =\frac{2.303 \log 2}{k}=\frac{0.693}{k} \\
k & : \text { 速度定数 } \\
n_{0}: & \text { 時刻 } t=0 \text { における放射能 } \\
n_{t}: & t \text { 時間後の放射能 }
\end{aligned}
$$

缄器組織の放射能を測定する場合には, 組織をSoluene -100 (Packard 社製) を用いて可溶化した。肝臓ならび に腎臓は摘出後, 生理的食塩水 $15 \mathrm{ml}$ を用いて血液を除 去した。濾紙にて水分を取り除いた後，生理的食塩水を 用いて $10 \%$ ホモジネートを調製した。ホモジネート $0.1 \mathrm{ml}$ に Soluene- $100,1.0 \mathrm{ml}$ を加光, $40^{\circ} \mathrm{C}$ の水浴中 に 1 夜温置して溶解した。血浆ならびに尿についても同
様にその $0.1 \mathrm{ml}$ に Soluene-100, $0.1 \mathrm{ml}$ を加えて溶 解した。トルエン系シンチレーター（PPO $5 \mathrm{~g}$ および POPOP $0.1 \mathrm{~g}$ をトルエンに溶かして $1 l$ にしたもの) $10 \mathrm{ml}$ を加え, 同様に液体シンチレーションスペクトロ メーターを用いて放射能を測定した（測定効率 55〜60 $\%$ )。

呼気に排泄させる炭酸ガスの放射能は，炭酸ガスをモ ノエタノールアミンに捕集し, その $0.2 \mathrm{ml}$ にジオキサ ソ系シンチレーター $10 \mathrm{ml}$ とメチルセロソルプを $2 \mathrm{ml}$ 加えて, 同時に液体シンチレーションスペクトロメータ 一を用いて測定した（測定効率 75〜80\%)。

\section{5. 糖 の 定}

ブドウ糖の測定は glucose oxidase を用いる Dahlqvist の方法 ${ }^{8}$ に従った。マルトースは生化学工業 K. K. 製の $\alpha$-glucosidase を用いてブドウ糖に分解した後同 様に測定した9)。

\section{実 験 結 果}

\section{1. マルトース-U-11 C の血中からの消失}

血管内に投与したマルトースならびにブドウ糖の血中 からの消失速度を比較してみた。

投与量 $0.1 \mathrm{mg} / \mathrm{kg}$ の場合には，投与したマルトース の血中放射能濃度の减少はブドウ糖を投与した場合にく らべてゆるやかであった（Fig. 1 )。血中放射能濃度の BHL は, マルトース 84 分, ブドウ糖 32 分であった。 さらに，マルトースならびにブドウ糖を $0.5 \mathrm{~g} / \mathrm{kg}$ を 投与した場合には，それらを $0.1 \mathrm{mg} / \mathrm{kg}$ に投与した場

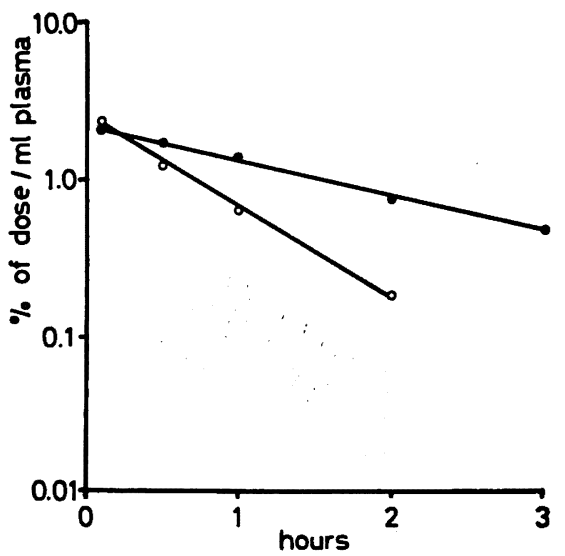

Fig.1. Time course of intravenously administered maltose- $\mathrm{U}-{ }^{14} \mathrm{C}$ and glucose- $\mathrm{U}-{ }^{14} \mathrm{C}$ in guinea pig.

Maltose-U-14 C (Sp. act. $326 \mathrm{mCi} / \mathrm{m}$ mole) and glucose-U-14 C (Sp. act. $180 \mathrm{mCi} / \mathrm{m} \mathrm{mole)} \mathrm{were}$ intravenously administered at dose of $0.1 \mathrm{mg} / \mathrm{kg}$ body weight, respectively. Values are the means of 7 determinations.

- — : maltose-U-14 $\mathrm{C}$, $0-0$ : glucose-U- ${ }^{14} \mathrm{C}$. 


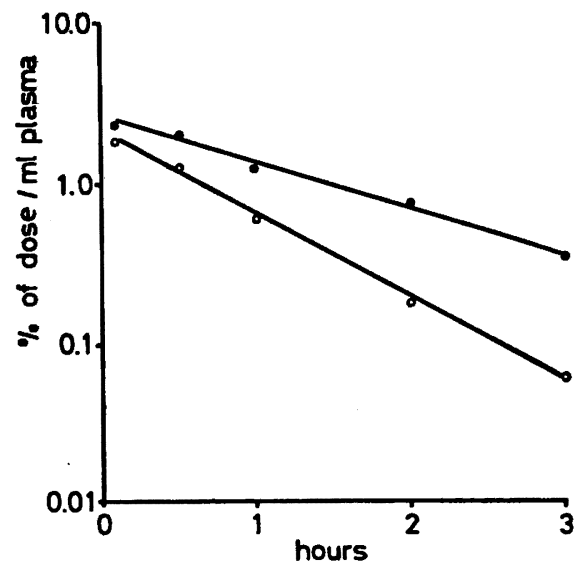

Fig. 2. Time course of intravenously administered maltose- $\mathrm{U}-{ }^{14} \mathrm{C}$ and glucose- $\mathrm{U}-{ }^{11} \mathrm{C}$ in guinea pig.

Maltose-U-14 $\mathrm{C}$ and glucose-U-14 $\mathrm{C}$ were intravenously administered at dose of $0.5 \mathrm{~g} / \mathrm{kg}$ body weight, respectively. Values are the means of 7 determinations.

$\bullet$ : maltose-U-14 $\mathrm{C}$, ॰- $\circ$ : glucose-U-U ${ }^{14} \mathrm{C}$.

合と同様に, マルトースの血中放射能濃度の減少はブド ウ糖のそれにくらべてゆるやかであった(Fig. 2)。それ ぞれの BHL はマルトース 76 分, ブドウ糖 32 分であ った。それゆえ，マルトースならびにブドウ糖を日常用 いる補液量に投与しても，これらの消失速度には影響を 及ぼさなかった。

しかしながら，血中に投与したマルトースの BHL は ブドウ糖のそれの約 2 倍半であったことは，マルトース が二煻類であるために代謝されにくいためか，あるいは マルトースがブドウ糖に分解された後に代謝されるため と考えられる。そこで，マルトースを投与した場合につ いてマルトースの消失とマルトースに由来してくるブド ウ糖の出現を経時的に観察してみた。

$0.1 \mathrm{mg} / \mathrm{kg}$ にマルトースを投与した場合には, マルト 一スそれ自身の BHL はブドウ糖のそれとほとんど同じ レヘル（25 分）であった（Fig. 3)。

一方， $0.5 \mathrm{~g} / \mathrm{kg}$ にマルトースを投与した場合にもマ ルトースそれ自身の BHL はブドウ糖の場合と差はなく， また $0.1 \mathrm{mg} / \mathrm{kg}$ に投与した場合と同レベル（26 分）で あった (Fig. 4 )。

$0.1 \mathrm{mg} / \mathrm{kg}$ ならびに $0.5 \mathrm{~g} / \mathrm{kg}$ にマルトースを投与し た場合には，いずれの場合るマルトース由来のブドウ糖 の出現をみた。すなわち、マルトース投与後 30 分でピ 一クに達し，それ以後は徐々に減少する㑯向が認められ た。それゆえ，血管内に投与されたマルトースはプドウ 糖に転換された後に利用されるすののようである。

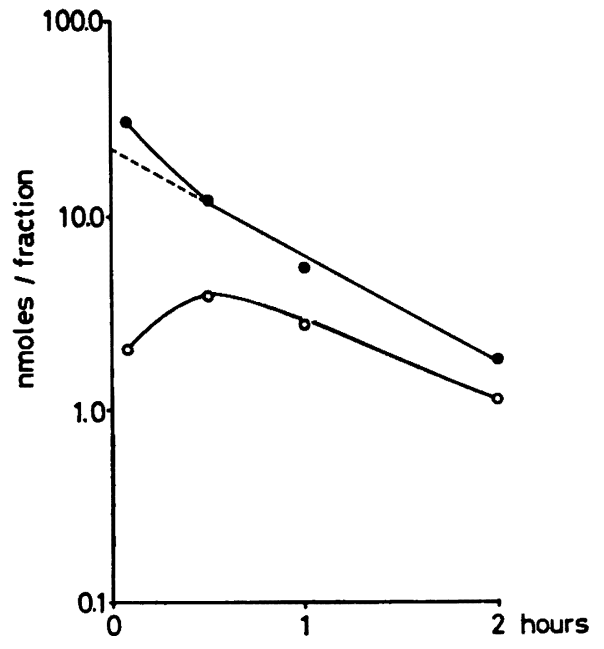

Fig.3. Time course of changes of administered maltose and glucose derived from maltose in guinea pig plasma.

Maltose-U-14 $\mathrm{C}$ was intravenously administered at dose of $0.1 \mathrm{mg} / \mathrm{kg}$ body weight. Each fraction is equivalent to $0.067 \mathrm{ml}$ of plasma, applied onto the charcoal column. Values are the means of 7 determinations.

- - : maltose,

$\circ$ - $:$ glucose derived from maltose.

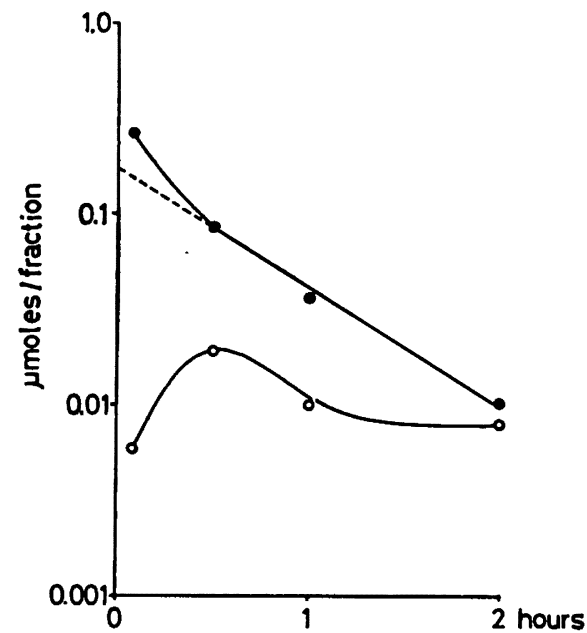

Fig.4. Time course of changes of administered maltose and glucose derived from maltose in guinea pig plasma.

Maltose-U-14 C was intravenously administered at dose of $0.5 \mathrm{~g} / \mathrm{kg}$ body weight. Each fraction is equivalent to $0.067 \mathrm{ml}$ of plasma, applied on to the charcoal column. Values are the means of 7 determinations.

-—_. : maltose,

$\circ$ - $:$ glucose derived from maltose. 
2. マルトースーU-14C を血中に投与した場合の藏器 内分布

マルトースならびにブドウ糖 $0.5 \mathrm{~g} / \mathrm{kg}$ を投与した場 合の葴器内分布を観察してみた。この場合，体内代謝の 中心臟器と考之られる肝臓，排泄臟器と考えられる堅臓 ならびにブドウ糖を直接のエネルギー源として利用して いる脳について，総放射能の分布を経時的に測定してみ た。

ブドウ糖-U-14C を投与した場合には，投与 5 分後に その約 $11 \%$ が肝臓に見いだされるが，この肝臟の放射能 は時間の経過とともに低下し， 2 時間後には 5 分後のそ れの $1 / 5$ 飞低下する（Table 1)。腎臓においては投与 5 分後にその約 $2 \%$ が見いたされるが，時間の経過ととも 飞低下し, 2 時間後には 5 分後のそれの $1 / 4$ 飞低下する。 さらに脳においては投与 5 分後にその約 $3 \%$ が見いださ れるが，時間とともに低下し， 2 時間後には 5 分後の約 1/2 飞低下した (Table 1)。

一方，マルトース-U-14C を投与した場合には，投与 5 分後にその約 $18 \%$ が肝䁍に見いたさされたが，この肝 臓の放射能は 30 分後にはブドウ糖投与の場合と同レベ ルに見いだされ，それ以降はブドウ糖と同様な経時的変 化を示した（Table 2)。腎臓においてはマルトース投与

Table 1. Distribution of radioactivities in the tissues after an intravenous administration of maltose- $\mathrm{U}-{ }^{14} \mathrm{C}$.

( 6 determinations)

\begin{tabular}{ccccc}
\hline \hline Organs & 5 & 30 & 60 & $120 \mathrm{~min}$ \\
\hline \multirow{2}{*}{ Liver } & 18.30 & 7.29 & 3.67 & 2.95 \\
& \pm 1.53 & \pm 0.45 & \pm 0.27 & \pm 0.21 \\
Kidney & 0.16 & 0.42 & 0.49 & 0.75 \\
& \pm 0.02 & \pm 0.03 & \pm 0.03 & \pm 0.03 \\
Brain & 0.30 & 0.94 & 1.12 & 1.21 \\
& \pm 0.02 & \pm 0.04 & \pm 0.06 & \pm 0.06
\end{tabular}

Values are expressed as percentage of doses (means $\pm \mathrm{SE}$ ).

Table 2. Distribution of radioactivities in the tissues after an intravenous administration of glucose- $U-{ }^{14} \mathrm{C}$.

( 6 determinations)

\begin{tabular}{ccccc}
\hline Organs & 5 & 30 & 60 & $120 \mathrm{~min}$ \\
\hline \multirow{2}{*}{ Liver } & 10.99 & 7.76 & 3.29 & 2.01 \\
& \pm 0.97 & \pm 0.35 & \pm 0.26 & \pm 0.13 \\
Kidney & 1.96 & 1.65 & 0.86 & 0.58 \\
& \pm 0.18 & \pm 0.11 & \pm 0.04 & \pm 0.02 \\
Brain & 2.75 & 2.22 & 1.72 & 1.21 \\
& \pm 0.21 & \pm 0.24 & \pm 0.07 & \pm 0.05
\end{tabular}

Values are expressed as percentage of doses (means $\pm \mathrm{SE}$ ).
5 分後にはわずか $0.2 \%$ 程度の放射能しか見いだされな かったが，時間の経過とともに增大し， 2 時間後には 5 分後のそれの約 4 倍になった。さらに脳においては，投 与 5 分後には $0.3 \%$ しか見いだされなかったが，時間の 経過とともに增大した。しかしながら，投与 2 時間後に 脳に見いだされる放射能はブドウ糖投与の場合と同レべ ルであった（Table 2)。

このようにマルトースを投与した場合の肝贜に見いた される総放射能の経時的変化はブドウ糖を投与した場合 のそれとほぼ同しょうな様相を示した。一方，堅臓なら びに脳内の総放射能の経時的変化はマルトースを投与し た場合，特異なパターンを示した。

3. マルトース-U-14C を投与した場合の呼気ならび に尿中の放射能

次に呼気ならびに尿中に見いだされるマルトース由来 の放射能を経時的に観察してみた。

マルトース $0.5 \mathrm{~g} / \mathrm{kg}$ を血管内に投与した場合には, 呼気中への ${ }^{14} \mathrm{CO}_{2}$ の排泄は投与 1 時間後から增大する が, 5 時間後には $41 \%$ に達し，それ以降は徐々に増大し て 12 時間後には $52 \%$ 飞達した（Fig. 5 )。一方、ブドウ 糖 $0.5 \mathrm{~g} / \mathrm{kg}$ を投与した場合には, 呼気中への ${ }^{14} \mathrm{CO}_{2}$ の排 泄は時間の経過とともに増大し，12 時間後には $40 \%$ て あった(Fig. 5)。それゆえ，マルトースの体内における 酸化はきわめて良く、ブドウ糖のそれに匹敵するすので あった。

マルトース $0.5 \mathrm{~g} / \mathrm{kg}$ を血管内に投与した場合の尿中 への総放射能の排泄を観察してみると，時間の経過とと るに增大し， 4 時間後には投与量の約 $4 \%$ に達し，さら にこの排泄は 12 時間後でる同レベルであった(Fig. 6)。 それゆえ，尿中への総放射能の排泄は比較的少なく，

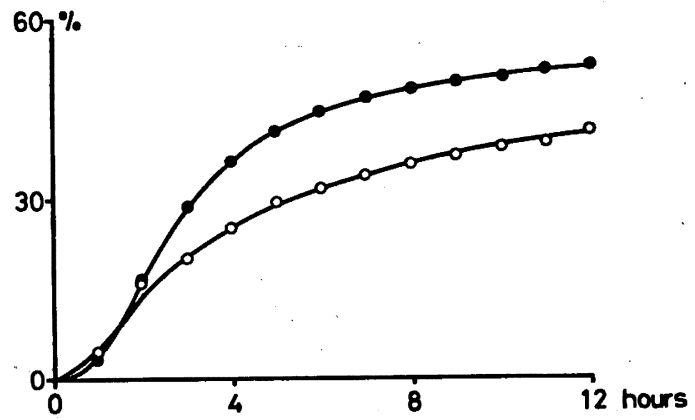

Fig. 5. Radioactivities expired in respiratory carbon dioxide.

Maltose-U-14C and glucose-U-14 $\mathrm{C}$ were intravenously administered at dose of $0.5 \mathrm{~g} / \mathrm{kg}$ body weight, respectively. Values are expressed as percentage of doses in guinea pig plasma. (means of 7 determinations).

-— : maltose, o- : glucose 


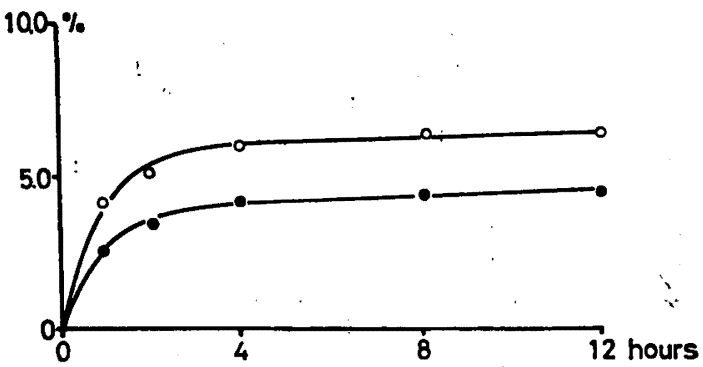

Fig.6. Radioactivities excreted in urine. Maltose-U-1ic $\mathrm{C}$ and glucose-U- ${ }^{14} \mathrm{C}$ were intravenously administered at dose of $0.5 \mathrm{~g} / \mathrm{kg}$ body weight, respectively. Values are expressed as percentage of doses in guinea pig plasma. (means of 7 determinations).

$$
\text { -. : maltose, ०—o: glucose }
$$

\section{とんど投与後 4 時間以内に観察された。}

一方，ブドウ糖 $0.5 \mathrm{~g} / \mathrm{kg}$ を血管内に投与した場合の 尿中への総放射能の排泄は，時間の経過とともに增大 し，4 時間後には投与量の約 $6 \%$ に達するが，それ以降 はほとんど同じレベルであった(Fig. 6)。すなわち，ブ ドウ糖の場合す尿中への総放射能の排泄は 4 時間以内に 観察された。

$$
\text { 考察 }
$$

二榶類であるマルトースを血管内投与した場合の血中 からの消失速度，ならびに代謝様相について，ブドウ糖 の場合と比較検討してみた。

$0.1 \mathrm{mg} / \mathrm{kg}$ といら锳量のマルトース-U-14 C を投与し た場合および $0.5 \mathrm{~g} / \mathrm{kg}$ といら日常用いる補液量のマル トースーU-14C を投与したいずれの場合においても血中 放射能の生物学的半減期 (biological half life : BHL) には差は認められなかった。またマルトースそのものの BHL とプドゥ糖のそれとの間にも差は認められなかっ た。

マルトースが体内で利用される場合, マルトースが直 接細胞膜を透過して代謝されるのか，あるいはブドウ糖 に転換された後代謝されるのかの二つの過程が考えられ る。前者についての可能性る否定はできないが，これを 証明することは現在容易ではなく，ここでは後者につい てのみ考察を加える。

マルトースを血管内に投与した場合，時間の経過とと すにマルトース由来のブドウ糖が血将中に出現し, 投与 後 30 分でピークに達し, それ以降は徐々に減少してい く傾向が認められた。またマルトースを血管内に投与し た場合の肝豚，とくに堅荿ならびに脳における総放射能 の経時的な分布はブドウ糖の場合とは異なり，マルトー スがプドウ糖に転換された後, 臓器組織において利用さ
れる様相を示していた。

マルトースをブドウ糖に転換する酵素は一般にマルタ 一ゼとして知られている。しかしながら, 哺乳類の体内 にこのよらなマルターゼ活性が存在しているかとうか は，あまり明らかでない。ヒト，モルモットにおいては 血㽬中には見いたされず10)，ウサギ，白ネズミならびに モルモットにおいては腎臓，肝臓，脳などにこのような 酵素活性の存在が見いたされるという報告もある(1)。事 実, われわれの実験結果からみてるマルトース-U-14C 投与後マルトース由来のブドウ糖が血中に出現したこと は肝胹ならびに蜸臓でのマルターゼ活性の関与が示唆さ れる。

また，血管内に投与されたマルトースのブドウ糖への 転換は徐々に進行していた。したがってマルトースは臓 器組織にブドウ糖を徐々に供給するるのと考えられる。 これは, 生体にとって最す好都合なエネルギー供給の状 態であろう。血管内にマルトースを投与した場合，尿中 への総放射能の排泄は少なく，また呼気への ${ }^{14} \mathrm{CO}_{2}$ の排 泄は比較的多かった。

さらにブドウ糖を血管内に投与した場合には，膆䕥か らのインシュリンの分泌を促進するといわれている ${ }^{12}$ が，マルトースを投与した場合にはこのような現象はみ られないといらず。このことは，マルトースからブドウ 糖は生成されるが，その転換速度が比較的緩徐であるた めであろら。

以上のことより，マルトースは生体組織に緩徐にブド ウ糖を供給するといら好ましい形態であると考えられ， 長期投与実験からその高い安全性も確認をみている ${ }^{13)}$ で，糖質栄養補液として有用なるのと考えられる。

結語

マルトースならびにブドウ糖を雄モルモットの陰茎静 脈より投与した場合の消失速度, 蔵器分布ならびに排泄 の様相を観察した。

1. $0.1 \mathrm{mg} / \mathrm{kg}$ ならびに $0.5 \mathrm{~g} / \mathrm{kg}$ に投与した場合の マルトースの BHL には差はなかった。マルトース投与 の場合には，マルトース由来のブドウ糖が出現し，投与 後 30 分でピークに達し, 以後徐々に減少の傾向を示し た。

2. 肝蔵, 腎臓, 脳における総放射能の分布を経時的 に観察してみると、マルトースを投与した場合はブドウ 糖の場合とは異なったパターンを示していた。

3. マルトースを投与した場合の呼気中への放射能の 排泄量は，ブドウ糖の場合に匹敵するるのであり，投与 後 12 時間で投与量の $50 \%$ であった。

4. マルトースを投与した場合の尿中への総放射能の 排泄量はブドウ糖とは差はなく，投与後 4 時間で投与量 
のおよそ $4 \%$ であった。

この報告の大要は第 26 回日本栄着・食糧学会 (1972.

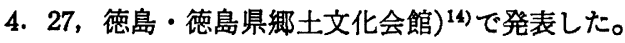

\section{文献}

1) Weser, E. and Sleisenger, M. H.: J. Clin. Invest., 46, 499 (1967)

2) Young, J.M. and Weser, E.: J. Clin. Invest., 50, 986 (1971)

3) Toyota, T., Ando, Y., Nishimura, H. and Hirata, Y.: Tohoku J. Exp. Med., 104, 325 (1971)

4）平岡幸治, 井上とも子, 池田隆行 : 基礎と臨床,
5, 2249 (1971)

5) Somogyi, M.: J. Biol. Chem., 86, 655 (1930)

6) Villee, C. A.: J. Biol. Chem., 205, 113 (1953)

7）堤 一彦，藤原 寛: 基礎と臨床，6,1112(1972)

8) Dahlqvist, A.: Biochem. J., 80, 547 (1961)

9）中川準子, 堤一彦, 上野山勤, 藤原 寛: 基礎 之臨床, 6, 284 (1972)

10）郡 英明：未発表

11) 藤井節郎: 最新医学, 受理

12) Kuzuya, T., Kanazawa, Y. and Kosaka, K.: Endocrinology, 84, 200 (1969)

13） 小寺敬一，三好 等，幸田昇一，野田富子，川島 裕造 : 応用薬理, 6, 251 (1972)

14）郡 英明，細谷憲政：栄養と食糧，25，168(1972) （昭和 47 年 7 月 20 日受理 経費著者負担） 